\title{
Biblical witness and economy in the writings of Klaus Nürnberger
}

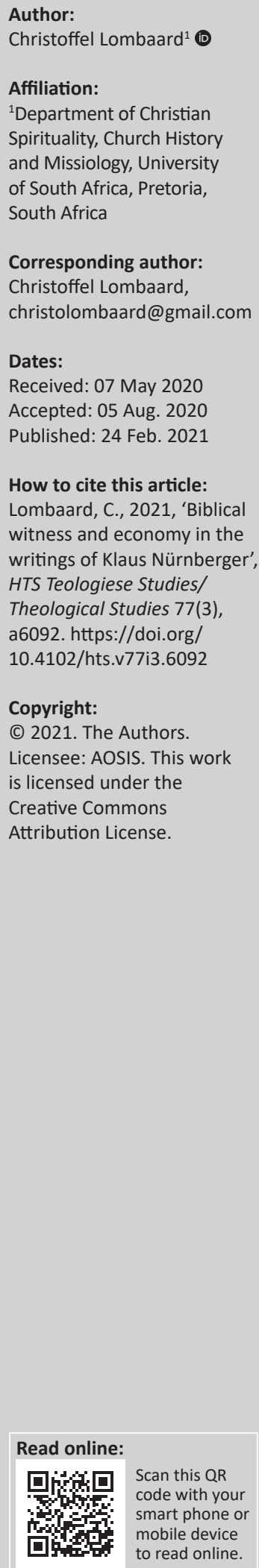

Given the purpose of this special edition, to consider theologically the implications of the Fourth Industrial Revolution, in this contribution, the writings of one of the important yet under-appreciated South African figures in thinking from biblical theology on matters of economics, Klaus Nürnberger, are taken into review. The relationship between (1) biblical witness and (2) faith and (3) deeds stands central in Nürnberger's theological framework. His interdisciplinarity has lasting validity because he takes seriously the disciplines involved, such as historical Bible scholarship, economic theory, social theory and the like. By his own reckoning, it is partly because of this kind of interdisciplinarity that Nürnberger's contributions on this topic had in a sense been marginalised. For this reason too, it is important in a new era to review sympathetically and appropriate critically the significant contributions of Nürnberger on the biblical witness to economic engagement.

Contribution: This research article, as a part of this themed collection, considers theologically the implications of the Fourth Industrial Revolution with a review of Nürnberger's contributions on the biblical witness to economic engagement. Nürnberger's interdisciplinarity in his contributions helps set the direction for future engagements in the dawning post-secular era.

Keywords: Klaus Nürnberger; Economic development; Biblical witness; Post-secularism; Theology; Interdisciplinarity.

\section{Introduction: Weaving believing and living}

Religious fundamentalism (which may in its current form be formally traced to the ed. Dixon [1910-1915] volumes) and modernist exclusion of religion from the public sphere (as Holyoake [1896] called secularism; see Benson [2004:83-98] for a fuller context and current reception) have at least two aspects in common, despite their directly opposing views on the place of religion in life. Whilst the former holds that religion should permeate, even dominate all expressions of human life, the latter holds that religion should be excluded from all expressions of human life. In both cases - the two commonalities - these views are held to the exclusion of any other in a markedly non-tolerant manner and then do so with the intent to serve humanity: it would be to our benefit to follow this one path.

Both these possibilities had been actively present throughout the previous century and are still very alive to our senses as expressions of the good life here in the first fifth of the present century. Both are much more straightforward possibilities, offering little room for nuance, alternatives or discrete permutations; in liberal democracies, and especially amongst the educated political, academic and economic elite in such societies, the reflex has been to the secular side of this oppositioning. The associated arguments and sentiments formed a construction of ideas and ideals that together were sensed to be right (this view has been most substantially traced in Taylor's famous A secular age, 2007; cf. locally Goosen [2007]) and to hold to a different view would often be felt to be somehow suspect.

It is in such a context that many of us have been educated, and it is in this broad cultural ambience that Klaus Nürnberger had studied and published. In his case, however, neither of these too easy options described above could be used to describe his writings. In Nürnberger's writing, as a current running throughout his publishing career, faith and reason interact. High theology systematic theologically, biblically-theologically bound in a markedly Lutheran manner (cf. Nürnberger 1985, 2006) - were were combined with, interpreted along with and related to 
burning issues of the day. Modernist compartmentalised faith-reason divides are not a part of his intellectual identity; the accompanying specialisation on one area to the exclusion of others does not constitute his academic make-up. In a manner becoming intellectually acceptable again in our unfolding post-secular era (see below), Reasoning from faith (in the title of Sands 2018), in other words, from overt existential or metaphysical commitments, and critical societal analytics go hand in hand for Nürnberger. (However, 'metaphysics' is not a part of Nürnberger's active terminologies; he prefers 'trancendence'. The use of the term 'metaphysics' here, and in similar instances below, is thus part of the analytical-interpretative placement of the thoughts of Nürnberger.)

In what follows below, the focus is on the economic aspect of Nürnberger's societal analyses, which constitute also his most prominent form of contextual engagement, and on how this is connected by him in perhaps surprising ways to the central messages of the Bible (hence reflecting the dynamic nature of the biblical witness), as a prime source for this existential or metaphysical orientation.

Nürnberger is a systematic theologian, with two doctorates, respectively titled:

- Glaube und Religion bei Karl Barth. Analyse und Kritik der verhältnisbestimmung zwischen dem christlichen Glauben und den anderen Religionen in $\S 17$ der 'Kirchlichen Dogmatik' Karl Barths (1967, Marburg, Dr Theol).

- Die Relevanz des Wortes im Entwicklungsprozess. Eine systematisch-theologische Besinnung zum Verhältnis zwischen Theologie und Entwicklungstheorie (1978a, Pretoria [University of South Africa], DTh).

This contribution is a further development of a paper presented at the 41st Annual Congress of the Association for the Study of Religion in Southern Africa, 04-05 September 2019, held at the University of South Africa. Conference theme: Religion and Economy. My thanks to colleague Klaus Nürnberger, who kindly read a post-conference version of the paper and made many helpful remarks towards better understanding his contribution on the Bible and economy.

In 2012, he was also awarded an honorary doctorate in Theology (DD) by the University of Pretoria, 'in recognition of the outstanding contribution he has made to Biblical Reformed Theology in South Africa, and outside its borders' (Text from the unpublished commendatio kindly provided by the then Dean of Theology at the University of Pretoria, J. Buitendag).

In his dissertation titles published already, his commitments show clearly: strongly Lutheran (cf. also Nürnberger 1985, 2006) and were on a strongly confessional topic (Nürnberger 1967 - which would in some ways be formative for his later theologising on ancestor veneration in Africa, in Nürnberger 2007) and Scripture-oriented reflection on improving the human condition (Nürnberger 1978a). The second doctorate is not fully divorced from the first, as might seem to be the case at first glance, with sections in the second reflecting the continued influence of the first (e.g. Nürnberger 1978a:92-107); more on this doctorate is given below, though.

In what follows, this interrelationship between religion and economy, alternatively: faith and society, or: biblical faith and money in Nürnberger's writings is outlined. The approach here is descriptive, although contextualised from within current trends and discussions; where appropriate, some illustrative quotes from his works are included. Nürnberger's writings from a wide time range and genres are referred to, with the tacit understanding that all writers develop over time, and that writing in a more popular work meant for South African church ministry is of a different order to writing, for instance, a dissertation, and yet again to a sermon in Germany. Indications below of continuances of themes and methodology, therefore, spring from a sympathetic reading to understand and indicate relationally rather than to criticise. This undertaking is in a sense easy, as - extraordinarily prolific an author as Nürnberger is - a remarkable sense of consistency emerges over time and genre in his works on the interrelationship between the biblical tradition and economy. Confluences of thought therefore surfaced without being forced. Moreover, references to publications other than Nürnberger's are in some instances included below, both to place him within current developments and to indicate the continued relevance of his work.

A further methodological step in preparing this contribution for publication included that the initial Religion and Economy conference paper from September 2019 was presented to him with a request for critical comments.

In this manner, an attempt is here made to present something of the interwovenness ${ }^{1}$ in Nürnberger's writings on the biblical faith and economy, topically and over time. In tracing these textures, seven of Nürnberger's publications seemed the most strongly indicative for this theme, with those seven constituting the primary framework for ordering the analysis below. These seven texts are as follows:

- The second dissertation, Die Relevanz des Wortes im Entwicklungsprozess. Eine systematisch-theologische Besinnung zum Verhältnis zwischen Theologie und Entwicklungstheorie (Nürnberger 1978a).

- Three books on development which to a substantial extent overlap in contents:

- Power, beliefs and equity : economic potency structures in South Africa and their interaction with patterns of conviction in the light of a Christian ethic (Nürnberger 1984; HSRC report 04/PO17).

- As a more freely available publication of this HSRC report, with the same content: Power and beliefs in South Africa. Economic potency structures in South Africa

1.'Interwovenness' is another example of typical post-secular language, cf., for example, Boersma (2011); Kourie (2015:1-9). 
and their interaction with patterns of conviction in the light of a Christian ethic (Nürnberger 1988).

- Prosperity, poverty and pollution. Managing the approaching crisis (Nürnberger 1999a).

- 'A consideration of the structure of economic society in South Africa' (Inaugural lecture, 17 February 1983, University of South Africa), published in: Vorster, WS (ed.) Church and industry. Pretoria: Unisa, 1-36 (Nürnberger 1983a; cf. Nürnberger 1994a, 1998).

- Two books on the biblical message, which similarly should be understood in close relation to one another:

- Theology of the biblical witness. An evolutionary approach (Nürnberger 2002).

- Biblical theology in outline: the vitality of the Word of God (Nürnberger 2004, as a less academic version of Nürnberger 2002).

\section{Unfolding the biblical witness - economy link}

In a 1995 published essay, 'The future of social justice research in the Hebrew Scriptures', one of the most international scholars of our time, Norman Habel (1995:277-291), characterises more the past than the future of the relationship between Bible interpretation and social engagement, namely as being a twofold enterprise, extending to (Habel 1995:278-280):

- Social justice in the Bible text - with a greater exegetical focus, namely on the past as reflected in the Bible texts.

- Social justice and the Bible text - with a greater focus on the present, in various ways drawing inspiration from the Bible in order to act in our time to correct a form of injustice.

This kind of two-pronged approach is by no means unfamiliar within South African theological scholarship relating to the Bible, with for instance - explicitly so - Albert Nolan's influential 1982 booklet Biblical Spirituality and Gerald West's (1991/1995) dissertation Biblical hermeneutics of liberation: Modes of reading the Bible in the South African context. This characterisation by Habel would no less fit the oeuvre of Klaus Nürnberger too - however, I would propose in a more sophisticated manner than when most exegetes tend to relate the Bible text to a current issue.

The clear commitment to practice theology for the poor (an oft-cited commitment, vocalised internationally most influentially by Gustavo Gutierrez [1996]; locally, e.g., Boesak [1984]; cf. Habel [1995:281-185]) has namely to my knowledge (cf. Lombaard 2015:1-7) never been tempered in South African exegetical circles by the foundational post-colonial insights of Gayatri Spivak (1988:271-313), in her famous essay 'Can the subaltern speak?': we can talk about the poor, Spivak convincingly argues, but not always with legitimacy on the poor, and never with validity for the poor. The 'garstig breite Graben' which Lessing (1979 [1777]:13) had for exegetes influentially acknowledged between the ancient and modern worlds, to temper Bible scholars' historical-reconstructive optimism, applies as much to the class divide between the current educated elite and those for whom the pretence is that they are being represented. They are not; the 'radically wide divide' between the poor and the educated (academic, political, economic) elite is such that the latter can never speak on behalf of the poor. What is more, as Scheffler (2011:192-207) had indicated exegetically, in the same way in which some Old Testament texts seem to plead on behalf of the poor, but do so really to obtain divine sympathy for the authorial self, namely by means of association with those whom God would bless, is to an extent paralleled by some Bible scholars. This is simply a part of the natural self-serving reflex of any establishment group (cf. Johnson 2019: Kindle location 1808-1946 on how that currently plays out in the South African labour force), who retain own power by ideological association with the underprivileged, paradoxically (though unintentionally) to the detriment of those with whom association is pleaded.

That, contrary to the way too quick reactions and misconceptions might have it, does not mean that the poor are doomed forever to be instruments in elite rhetoricians' self-absorbed pronouncements only (though they are that too). The agency of the poor (cf., e.g., Brady et al. 2016) as much as the openness to let all decide for themselves what would be good for them, as leading development economist Amartya Sen (2005:3-16) has argued, ought never to be denied. The poor are never victims only, nor perpetrators only (as xenophobic sentiment for instance likes to portray the matter), but display independence and activity too (cf. Seekings \& Natrass 2016), even in the face of constant structural-economic hurdles (with as an excellent example Van Onselen's prize-winning 1996-published historical case study, The seed is mine: The Life of Kas Maine, a South African sharecropper, 1894-1985). In this aspect, concepts such as those of conscientisation as developed by, for instance, Paulo Freire (cf. 1973) were important.

This is the kind of sensitivity to issues of economic well-being found with Nürnberger, although in writings which often much predate these insights touched upon all too briefly in the paragraph above. Nürnberger's initial studies had been for the BSc (Agricultural Economics) degree, and his early career in a government department for development (then called the Department of Native Affairs) explains in part his life-long interest in and insight into practical matters of development and economy. ${ }^{2}$ That this interest has remained with him can be traced throughout his publications. The nonprescriptiveness and the unassuming nature on which he insists in economic development work (e.g. Nürnberger 1978a:334-361, 1983a:23), which corresponds to the insights

2.This stands in contrast to the usual professional biographies of exegetes, which has led to the following criticism (quoting below from Lombaard 2015:4; cf. Nürnberger 1990:45 on clergy):

$[N]$ o exegete has the training as a political scientist, development economist, social worker or some such background required for direct assistance to the marginalised Such direct alleviation cannot be the intention of Bible scholarship: marginalised. Such direct alleviation cannot be the intention of Bible scholarship: There is no straightforward link between understanding a biblical text anew and lessening misery. Such a linkage is more remote and may only be built by employing, for instance, theories of social and spiritual capital adapted to African social and religious constructions. The assumption that an unmediated or immediate connection between the ancient Bible text and current contexts exists is certainly a (dominant) part of broader African societies' many spiritualities. However, intellectuals should know better. 
from Spivak and Sen on agency mentioned above, find their roots in a different place, namely in his understanding of the Bible. He asserts, for instance, that although being rich is of itself not negative in Pauline theology (on which Nürnberger [1978d:163-171, 1983b, 1995:63-76] draws most regularly within the biblical resources, at times entrusting other parts of the biblical literature to colleagues such as Decock [1978:153-162]; Rosner [1978:135-140]; Wittenberg [1978:141-152]), moves towards equality of income (cf. Nürnberger 1983a:28-29, and later, rather equality of production) better show the humility of Christ, who ought to be emulated in dealing with matters of economic justice, namely in a manner that allows everybody involved their dignity yet excuses no one for inactivity (ed. Nürnberger 1978c:164-170; cf. Nürnberger 1988:222). He dismisses naive fears of the rich becoming poor in one fell swoop, and the poor, rich (Nürnberger 1978a:338). Addressing The scourge of unemployment in South Africa (the title of Nürnberger's 1990 booklet title) hence includes, apart from practical suggestions (Nürnberger 1990:33-43), also the principled positive valuing of people from the perspective of biblical witness, the church and their own inherent worth (Nürnberger 1990:8-9, 43-47).

The global economic system, with its unequally spread geopolitical gravity, is taken into extensive review by Nürnberger (1994a, 1994c:47-70, 1999a:19-140, for instance), ${ }^{3}$ also in how it affects South Africa, with its own internal structural-economic equalities (Nürnberger 1983a:10, 1988:2-4, 8-9, 13-133). He is thoroughly aware of all major socio-political systems of our time, ranging from free-market capitalism to stringent socialism, with various permutations of these two alternatives (Nürnberger 1991a:75-84, 1998:28-127). Either to disregard or to remain inert to the realworld imbalances of the international political economy would be unacceptable; hence, policies are suggested for the economic centres and peripheries, also in their interaction (Nürnberger 1999a:359-458), in order to improve equilibria. This is because the economic world is not unrelated to the ideational world. Therefore, the role of convictions, faith and ideology as they relate to economics are thoroughly discussed (Nürnberger 1984, 1988:135-261, 1999a:141-266). ${ }^{4}$ Economics has its own 'cosmology' too (Nürnberger 1999a:280-282), with all schools of economic thought containing underlying values (Nürnberger 1998:160-164). Nürnberger (1999a:364-367) places some emphasis on the role of 'primary groups' as economic mitigators, which emphasis - interestingly thematically approaches the newest major work by Afrikaans philosopher Danie Goosen (2015), Oor gemeenskap en plek: anderkant die onbehae. Hopelessness and a sense of despondency in situations of economic despair go along with modernity's privatised religion (Nürnberger 1999a:157-162), whereas Christianity in normalised position (see below on

3.Cf. the analysis of Van den Berg (1998) on different aspects of the economic reality including in a second part of the book also major church documents from the previous century on economic matters. Koch (2014) provides for a current, extensive overview of the relationship between religion and economy.

4.The types of conviction (meaning systems/faiths, identification, economicideological commitments, etc.) identified in Nürnberger (1988:141-261) (employed in a number of his publications), which includes also the psychological dimensions associated with power play, is one of the most productive analytical frameworks have yet come across( cf. Nürnberger 1984). post-secularism) offers a more humane, fulfilling alternative, including human rights and opposing the unfair distribution of power (Nürnberger 1999a:163-180, 367-370), amongst other socio-political factors. Economic involvement includes social aspects too (Nürnberger 1995:22-42).

Nürnberger (1978a:2, 447, 1999a:3-8; cf. Nürnberger 2012:1-10) often writes from a sense of concern about an impending socio-economic catastrophe, not in the typical eschatological or perhaps apocalyptic sense found within (usually) evangelical Christianity, but with apprehensions on the suffering of people, related as it is also to ecology. Both major economic systems of our present and recent past, capitalism and socialism, have failed the test of ecological care (Nürnberger 1998:181), with all the possible calamitous repercussions. This failure on the part of our economic systems occurs not because of mere miscalculations; 5 'both ideologies have to reconsider not only their practice but, more fundamentally, their basic presuppositions' (Nürnberger 1998:181-182).

The latter non-partisan criticism (Nürnberger 1978b, 1998:160-163 also evaluates critically the gains and problems of both capitalism and socialism; cf. Nürnberger 1988:218) is expressed within the context of considering the limits to economic growth, with the priorities for a better future, Nürnberger (1998:191) declares, which are traceable directly from 'the Graeco-Christian heritage' in which we stand, and which are (Nürnberger 1998:191-197):

- 'The preservation of the natural world'

- 'Material sufficiency for all'

- 'Equity in the distribution of inputs and benefits'

- 'Concern for the weak and vulnerable'

- 'Balance in the satisfaction of various kinds of needs'.

Whereas matters ecological certainly remain prominent on the theological agenda (cf., e.g., Conradie 2006; Du Toit 2018), zero economic growth options as a corollary are less so. Such economic options have a longer history of academic consideration than might offhandedly be assumed (cf., Galtung 1973:101-114, which source Nürnberger cites), but have in the recent decade attained much greater urgency. This is seen with, for instance, Rosa and Henning's (eds. 2017) The good life beyond growth and in the work locally of Fioramonte (2017) on the Wellbeing economy. The resonance of Nürnberger's work with these developments is tangible (e.g. Nürnberger 1978a:362-400 on the limitations to economic growth); this is perhaps because he is conversant with works which would stimulate corresponding insights. (Parallels do not necessarily presuppose direct influence.) Although he does not refer to them extensively, Nürnberger is, for instance, well aware of the contributions of Max Weber (especially, The Protestant ethic, 1926, although he does not make much of Weber's sociology of religion; cf. Otto 2005), Tawney (Religion and the rise of capitalism, 1969 [1926]) and the 1987 Stackhouse study, Public theology and political economy:

5.'Human beings are neither angels nor devils. They are also not infallible... [but can be] bedevilled by irrational reactions rather than guided by sober analysis' (Nürnberger bedevilled by irrational reactions rather than guided by sober analysis' (Nürnberger
1998:159). Hence, also the poor should not be idealised (Nürnberger 1988:222), but their plight, on religious grounds, must be addressed (cf. Van Wyk 2011:2). 
Christian Stewardship in modern society, that traces early church impulses into modern business corporations. Already in 1978 in his second dissertation, he referred to the work of Frantz Fanon (1976; The wretched of the earth), long before Fanon had attained his canonical status of late, and to major scholars of development of the time such as Galbraith (1958; e.g. The affluent society). He also draws on publications by politicians such as Julius Nyerere, sociologists such as Peter Berger and, especially, Lawrence Schlemmer (1978:49-56), a few Bible scholars such Martin Noth and, particularly, Ernst Käsemann, and the systematic-theological leading figures of the time, Jürgen Moltmann, Wolfhart Pannenberg and Paul Tillich.

It would be fair to conclude from the above description (cf. also Nürnberger 1991c:175-187) that the stark criticism by Jacques Ellul (1972:154) - 'I hardly ever find Protestants speaking with competence on political economics, sociology, social psychology, or political science' - would count Nürnberger amongst the exceptions. Characteristic of Nürnberger's work, already mentioned in passing above, is, however, an explicit transcendent framework, which will now be placed into greater focus.

\section{Imagine there's no no-heaven (with apology to John Lennon)}

In almost all of Nürnberger's works, he stresses the importance of the biblical witness as an existential, metaphysical source or orientation from which actions towards economic justice cannot but flow. 'The Biblical faith in all its forms is based on a personal relationship of mutual selfgiving and faithfulness between God and man' (Nürnberger 1983a:22), which plays out as 'concern' - a key word for Nürnberger (1983a:23-24) - as care for others, which is related to human rights and justice, but both transcend and guarantee those, because of the giving nature of 'concern'. This orientation to and from the Bible is not practised in any fundamentalist or biblicist manner (cf., Barrera [2013] in somewhat more literalist mode on the relationship between the Bible and economic ethics), in which decontextualising proof texting would be a manner of Scriptural 'application'; nor, however, in a primarily exegetical manner that would satisfy the protocols for valid scholarship accepted amongst Bible scholars who would be text-oriented rather than application-oriented.

When Nürnberger (1995:63) writes about the Bible, he does so as a Systematic Theologian, rather than as an exegete, taking as a matter of foundational principle the Scriptures as prime motivation for all else. The role of God in the world is understood as 'including the economy ... the entire creation in all its dimensions'. He seeks his roots explicitly in the Judeo-Christian tradition, both for personal and for culturehistorical reasons - the latter, as therein lies the origins of our current economic practices. Basic religious convictions themselves open to critical scrutiny (also when reading the Bible itself - cf. Nürnberger 2009), then form with a firm sense of validating the framework for evaluating economic ideas and practices and their effects on humanity (cf., Nürnberger 1988:263-317).
This pattern, that faith springs from the biblical witness and leads to concrete actions (or, this train of thought: Bible faith - deeds), can, for instance, be seen in the subtitles of his two-volume 2016 Systematic Theology, which carry the respective subtitles Life in the presence of God (Nürnberger 2016a), the contents of which is, notably, formulated in toto around the Word (biblical witness) as the central motif (binding, e.g., the topics of church, ministry and sacraments together; cf. also Nürnberger 2019), and Involved in God's project (Nürnberger 2016b). With Nürnberger, the text is the 'pre-text' for active involvement in the context.

Theology is 'the basic thrust of biblical faith' (Nürnberger 1998:223), in making sense from the Bible what to believe (Nürnberger 2016a:2-30), which is the purpose of the 'Weltangehendes Wortes' (Nürnberger 1978a:40, to which in a contemporaneous, similar formulation his Lutheran reflex adds, in Nürnberger 1978b:18, '. . als Gesetz und Evangelium'). Therefore, in an essay titled 'Faith and economics' (Nürnberger 1998:223-241), Nürnberger (1998:223) follows through on the principle that one cannot 'pretend as if collective predispositions, attitudes, decisions and actions were not ultimately based on convictions'. The transcendent has concrete effect, always and in everything, which must be recognised. As in another context, British author Aldous Huxley (1937) had formulated the same awareness of a universal situatedness of the human condition:

It is impossible to live without a metaphysic. The choice that is given to us is not between some kind of metaphysic and no metaphysic; it is always between a good metaphysic and a bad metaphysic, a metaphysic that corresponds reasonably closely with observed and inferred reality and the one that doesn't. (p. 252)

Problems hence always contain ideological and religious roots too (Nürnberger 1978b:18). These 'convictions' another key term for him -Nürnberger writes on are therefore not in the first instance related to, for example, the three 'masters of suspicion' (à la Ricoeur 1970), Marx, Freud and Nietzsche, as the traditional intellectual progenitors and hence amongst the most important points of final reference of our time. In his less materialist intellectual framework, such final reference is sought in something more foundational: 'Es geht uns um eine im Wort selbst angelegte Religionsund Ideologiekritik mit gesellschaftlichen Konsequenzen' (Nürnberger 1978a:91).

Already in his 1978 dissertation, Nürnberger (1978a:2, 447-448, 452) formulates substantively this existential dimension to multi-disciplinary work (on which, more below). This he finds in the Bible as a gateway between the divine and the development work on which he writes in the second half of the dissertation. Such work is the concretised product of faith (Nürnberger 1978a:5-39), which is on its part the existential consequence of the word/ biblical witness. Nürnberger (1978a:40-219) hence considers the Bible extensively, establishing a pattern followed in some of his later books too. (This runs parallel to Ellul 1984 [1950].) After considering in depth the relationship 
between theology and development work, Nürnberger (1978a:450) concludes with a sentence that is to a substantial extent a summary of his life's work: 'Hier geht es also um die Relevanz des Wortes angesichts der Bedrohung der Menschheit durch die weltwirtschaftliche Entwicklung'.

Nürnberger's (1975:23-180) first Systematic Theology, published in Afrikaans, therefore unsurprisingly devotes a substantial opening part to the Bible as Word of God (not meant synonymously, but with the Word of God as the proclaimed gospel, which is based in the biblical witness), with thematics such as law and grace again, as in his dissertations (cf. also Nürnberger 1981:25-47), showing his Lutheran background. This, not meant as an implied criticism, but as indicating a feature of Nürnberger's (1985:8-12, 21-30) engagement with the Bible, which comes to the fore often when he discusses the Bible under rubrics such as law and grace or the Lutheran Two Kingdoms metaphor on the relationship between church and society. The Two Kingdoms theology should, however, not be misunderstood as the church drawing away from society, but the exact opposite (cf. Nürnberger 1983a:25, 1985:25-30, 1994b:118-146), based on the 'Bible - faith - deeds' train of thought (which precludes a double morality at times ascribed to Luthernanism) indicated above.

The biblical witness thus provides the 'Tiefendimension' (Nürnberger [1978a:91] - a term Nürnberger (cf. 1983a:1) prefers to other similar hermeneutical and phenomenological concepts - to human life, namely (in a somewhat uncharacteristically philosophical moment) as that beyond which nothing more is, and from which therefore springs all other matters. The biblical texts provide historical-contextual emancipating reactions to deeply experienced humanity, in diverse contexts. Human well-being includes that the usually acknowledged human needs (biological, etc.) are at once complemented by the spiritual needs, as we require a sense of meaning, belonging and being in control of much of our existence (Nürnberger 2016b:394-405).

When writing directly about the Bible, Nürnberger (2016a:121142) fully acknowledges that the Bible has had a developmental history, which historical-critical analyses not all local Systematic Theologians grasp equally well (cf. Le Roux 1994:27-51), although some do (e.g. König 1982). Nürnberger wrote two volumes akin to the scholarly genre amongst exegetes of Biblical Theology, which genre usually seeks to systematise historically (rather than dogmatologically) the Bible texts around a theme or a set of themes: Theology of the biblical witness: An evolutionary approach (Nürnberger 2002) and Biblical theology in outline: The vitality of the Word of God (Nürnberger 2004). In these two publications, Nürnberger's approach to the Bible can be seen in a most systematised manner. Both start off with substantive hermeneutical orientations, in which an own understanding of the processes through which the Bible texts had come into being, as is the habit with the genre of Old Testament Theology and New Testament Theology, is given. Rather, closer to the genre of the Introduction in Old and New Testament Studies, extant understandings are summarised, although in this case the newer developments, for example, on Pentateuch theory over recent decades, are not taken up. The historical questions are on the table, but in their older versions, and explained in too systematic-theological manners to be of use within Biblical Studies courses with a primarily exegetical intent. More is said about the Bible than are texts analysed in their compositional and redactional histories. The Bible is fully acknowledged as historically formed; yet, it contains 'Divine truth' (Nürnberger 1991b:75). Developments in the texts are, however, less historical reinterpretation (in the influential mode identified by Von Rad 1969) than they are, for Nürnberger (1991b:75) progressive revelation - the latter in a form that seems influenced by liberation theology rather than by traditional dogmatology, as 'a progression in theological insight in the direction of a greater humanisation of social structures'. Nürnberger thus remains a Systematic Theologian, for whom the formative theological and ethical implications from the Bible texts are important. The historical situatedness of the Bible texts is not inconsequential and must be taken seriously, but their implications for individuals, the church and society take primacy. When in the second part of both volumes 'biblical paradigms' - the patriarchs of Israel, the exodus and taking of the land, the Israelite kingdom, priesthood, covenant and law (and grace), creation (an approach that reminds of the thematic approach of, e.g., McGrath 1999:35-81, 88-108) - are considered, they are traced from the Old Testament to the New. The history told in the texts are retold, with some historical matters considered and some current implications pointed out. The underlying intention with these volumes had clearly been to come to terms with, and to communicate in a pastorally supportive manner, the biblical material historically conceived, but meant for existential nourishment and contextual application rather than for textual-analytical purposes.

Nürnberger's (1998:233-240) formative frame of interpretation on political-economic alternatives is the biblical witness too. Economy is, therefore, evaluated, broadly, from a faith in/ formed by the Bible. In greater detail, drawing on Bloch (1970), Nürnberger (1998:225) for instance indicates that Marxism stands in a line with Christianity. More clearly stated, 'Marxism can largely be understood as a secular appropriation of Biblical concerns', which Christianity ought to acknowledge too (Nürnberger 1988:222). Unintentionally mirroring Carl Schmitt (1934 [1922], 2008 [1970]), that 'Alle prägnanten Begriffe der modernen Staatslehre sind säkularisierte theologische Begriffe' (cf. Lombaard 2019; Schmitt 1934:49), Nürnberger (1998:225226; cf. Nürnberger 1988:218-222) traces some concrete parallels between Christian and Marxist intent. That the same can be done with capitalism is equally possible (Nürnberger 1998:228; cf. Nürnberger 1988:218-222), although Nürnberger does not, in this regard, explore the Weberian thesis that capitalism is traceable to Calvinist roots, which would seem a reasonable argument to follow in this instance.

It is on this intersection, bringing the Bible as theologically formative metaphysical or transcendent orientation into dialogue with development economics, that Nürnberger is at his strongest. 


\section{Placing theology and interdisciplinarity}

Nürnberger (2016a:12-17) understands the context in which he works as the post-modern. I would, drawing on his writings, rather place him within post-secular context. Nürnberger's commitments and writings certainly do not fit well with the earlier modernist emphases on the atomistic aspect, ${ }^{6}$ the strict separation of different aspects of reality (e.g. ethics from science, in which debate Nürnberger partakes, with Bentley 2018:1-5; Nürnberger 2013, 2010; cf. Nürnberger 2009:281-285) and a satisfaction with historical explanations in the Humanities as being fully sufficient. A closer approximation of Nürnberger would be the postmodern, in which the relational replaces the atomistic aspect, which relationality clearly characterises accurately Nürnberger's overall oeuvre. However, 'text' as the central explanatory metaphor of post-modernism (replacing the role history has in modernism), with its internal referentiality only, precludes the realism of the divine in Nürnberger's (cf. 1999b:87-103) theological disposition. God cannot for Nürnberger be a metaphor central to a community of interpretation, as a post-modernist understanding would cast a religious community; for him, as seen above, the metaphysical is fully concrete, and foundationally determinative of all that eventuates.

The post-secular is namely constituted by recouping aspects from the past, such as the historical orientation from modernism and the relational inclination from postmodernism, along with the ontological realism from premodern thinking, although with the naïvetes of the latter now tempered by the gains from modernism-postmodernism. These are related to experientially - with the latter the central key for validity (cf. Pretorius 2008:147-165) in this unfolding religio-cultural climate. (Recent texts on post-secularism include eds. Ingman et al. 2016 and eds. Nynäs, Lassander \& Utriainen 2012.)

The accompanying philosophical neo-realism and neomaterialism (cf. respectively Schreiber 2012:1-8 and eds. Ingman et al. 2016) find direct reflection in the understanding of the influence of the divine within society. No longer are aspects of faith publicly eliminated, marginalised and confined to the personal sphere (as intuitively with modernism) or metaphorised and socially isolated (as intuitively with post-modernism). Increasingly, religiosity is reflexively accepted as a normal part of day-to-day society, neither almost instinctively to be privileged or ostracised, with inclusive diversities an evolving implicit pattern in society. In academia, on its part, multidisciplinarity can within such an intellectual atmosphere more readily include matters religious, with such a more broadly inclusive multi-disciplinarity a noticeably growing feature of this presently unfolding religio-cultural climate (Lombaard 2016:1-6).

6.As Taylor (1973:13) formulates the modernist reflex, "When economics and theology are discussed together, it is usually on the level of individual ethics'.
From the characterisation of Nürnberger's work above, the latter kind of intellectual climate makes for a precise fit. He namely expressly pleads for 'a multidimensional and comprehensive approach. Economic measures must become part of an integrated religious, cultural, social, economic and political programme' (Nürnberger 1994a:46). This he takes even further, arguing that the term 'multi-disciplinarity' should be replaced by 'supra-disciplinarity', which would, because of the urgency of the matters at stake (Nürnberger 1999a):

Allow representatives of all disciplines to suspend, at least temporarily, their professional preoccupations and take a fresh look at the evidence through the eyes of their peers from other disciplines... to activate our expertise in a form which is compatible with the whole body of knowledge and accountable to the whole process of world development. (pp. 8-10)

The classical view of the unified intellectual project in service of society clearly underlies this sentiment. That theology and economics and development could conceivably work together productively may not have been an always accepted notion in much of 20th century academia, but Nürnberger's (1990:8) argument and practice are that metaphysics and care are inextricably associated with one another - as he exclaims, 'God's redemptive love ... makes us active!'. Participating in alleviating problems within society (cf. Nürnberger 1994a:49-58) is seen unapologetically from a theological angle, even though with his grounding in developmental economics, Nürnberger has the referential means to speak of the church in more functionalist or corporatist language. However, he writes on the role of the church in society not as the lure within modern thinking, as a non-governmental organisation (NGO) or as a faith-based organisation (FBO), but as an expression of the Word of God (e.g. in Nürnberger 2016a).

That this orientation is based neither on fundamentalist religious commitments nor on (often associated) uninformed economic development initiatives adds validity to casting Nürnberger's contributions within the post-secularist mode. The gains of modernism-post-modernism are clear to see in his writings.

That he goes further, beyond this, however, speaks from the language employed by Nürnberger too. He, for instance, formulates a positive position on 'experiential realism' (Nürnberger 2016b:476-482), and characterises his own 2016 Systematic Theology as 'an experiential approach' (Nürnberger 2018:1-11) - with 'experience', as noted above, one of the key features of the post-secular manner of being.

Interestingly, this kind of understanding of working across disciplines which includes theology too is already present in the closing section of Nürnberger's 1978a dissertation; it is not a new sensibility with him. The remarkable currency of that formulation is such that it deserves to be carried further into the present post-secular discussion (Nürnberger 1978a):

Mit dem Aufweis der Relevanz des Wortes in einem Problembereich von solcher Größenordnung und Dringlichkeit dürfte aber für die Theologie als solche ein neuer Aufgabenbereich innerhalb des Kontextes 
moderner Wissenschaftlichkeit zugewiesen worden sein. Die Arbeit hat gezeigt, daß die Existenz und Bedeutung tiefendimensionaler Festgelegtheiten in der wissenschaftlichen Theorie und Praxis, wie in den Vollzügen menschlichen Lebens überhaupt, nicht übersehen werden dürfen, daß sich aber unter den immanentistisch arbeitenden Wissenschaften keine findet, die diese Aufgabe in wissenschaftlicher Strenge aufgreifen, tiefendimensionale Festgelegtheiten nicht nur bewußt machen, sondern auch sachentsprechend zur Sprache bringen und als solche angehen kann. Die Theologie füllt hier eine Lücke aus, die bisher nur zum Schaden der wissenschaftlichen Sache, und schließlich des Menschen ignoriert, verdrängt, immanentistisch verfälscht oder vernachlässigt worden ist. Die apologetische Haltung der Theologie den anderen Wissenschaften gegenüber ist, wenn sie schon auf Grund ihrer eigenen Sache, der Dynamik der Selbstgewährung Gottes zum Heil zulässig wäre, von hier aus ganz unberechtigt. Und je eher die Theologie an dieser Stelle mit aller Selbstverständlichkeit ans Werk geht, je überzeugener wird ihr spezifischer Beitrag auch für die anderen Wissenschaften sein. (pp. 451-452)

\section{Acknowledgements}

This contribution is a further development of a paper presented at the 41st Annual Congress of the Association for the Study of Religion in Southern Africa, 4-5 September 2019, held at the University of South Africa. Conference theme: Religion and Economy. My thanks to colleague Klaus Nürnberger, who kindly read a post-conference version of the paper and made many helpful remarks towards better understanding his contribution on the Bible and economy.

\section{Competing interests}

The author declares that he has no financial or personal relationships that may have inappropriately influenced him in writing this research article.

\section{Author's contribution}

C.L. is the sole author of this research article.

\section{Ethical considerations}

This article followed all ethical standards for research without direct contact with human or animal subjects.

\section{Funding information}

This research received no specific grant from any funding agency in the public, commercial or not-for-profit sectors.

\section{Data availability}

Data sharing is not applicable to this article as no new data were created or analysed in this study.

\section{Disclaimer}

The views and opinions expressed in this article are those of the author and do not necessarily reflect the official policy or position of any affiliated agency of the author.

\section{References}

Barrera, A., 2013, Biblical economic ethics: Sacred Scripture's teachings on economic life, Lexington Books, Lanham.

Benson, I., 2004, 'Considering secularism', in D. Farrow (ed.), Recognizing religion in a secular society, pp. 83-98, McGill-Queens Press, Montreal.

Bentley, W., 2018, 'Balancing the transcendence and immanence of God in Nürnberger's theology', Verbum et Ecclesia 39(1), 1-5. https://doi.org/10.4102/ ve.v39i1.1917

Bloch, E., 1970, Atheismus im Christentum: Zur Religion des Exodus und des Reichs, Rowolt, Reinbek.

Boersma, H., 2011, Heavenly participation: The weaving of a sacramental tapestry William B. Eerdmans, Grand Rapids, MI.

Boesak, A., 1984, Black and reformed: Apartheid, liberation and the Calvinist tradition, Orbis Books, Maryknoll, NY.

Brady, D. Burton, L. Piven, F. \& Minnite, L, 2016, 'Poor people's politics', in The Oxford handbook of the social science of poverty, Oxford University Press, Oxford.

Conradie, E., 2006, Waar op dees aarde vind mens God? Op soek na 'n aardse spiritualiteit, Lux Verbi, BM, Wellington.

Decock, P.B., 1978, 'Poverty and riches in the theology of Luke', in K. Nürnberger (ed.), Affluence, poverty and the Word of God, pp. 153-162, Lutheran Publishing House, Durban.

Dixon, A.C. (ed.), 1910-1915, The fundamentals: A testimony to the truth, 12 vol., The Testimony Publishing Company, Chicago, IL.

Du Toit, C., 2018, 'Science and religion in African context: The role of African religions in addressing the challenge of climate change and sustainability', paper presented at the Department of Biblical and Ancient Studies, University of South Africa, 23 October

Ellul, J., 1972, False presence of the kingdom, Seabury, New York, NY.

Ellul, J., 1984 [1950], Money and power, InterVarsity Press, Downers Grove, IL.

Fanon, F., 1976, The wretched of the earth, Penguin, Harmondsworth.

Fioramonte, L., 2017, Wellbeing economy, Pan Macmillan, Johannesburg.

Freire, P., 1973, Education for critical consciousness, Continuum, New York, NY.

Galbraith, J.K., 1958, The affluent society, Hamilton, London.

Galtung, J., 1973, 'The "limits of growth" and class politics (review article)', Journal of Peace Research 10(1-2), 101-114. https://doi.org/10.1177/002234337301000107 Goosen, D., 2007, Die nihilisme: Notas oor ons tyd, Praag, Pretoria.

Goosen, D., 2015, Oor gemeenskap en plek: Anderkant die onbehae, FAK, Pretoria.

Gutierrez, G., 1996, Essential writings, Orbis Books, Maryknoll, NY.

Habel, N., 1995, 'The future of social justice research in the Hebrew scriptures', in J.L. Mays, D.L. Peterson \& K.H. Richards (eds.), Old Testament interpretation: Past, present, and future: Essays in honor of Gene M. Tucker, pp. 277-291, Abingdon Press, Nashville, TN.

Holyoake, G.J., 1896, English secularism: A confession of belief, Library of Alexandria, Chicago, IL.

Huxley, A., 1937, Ends and means: An enquiry into the nature of ideals and into the methods employed for their realization, Chatto \& Windus, London.

Ingman, P., Utriainen, T., Hovi, T. \& Broo, M. (eds.), 2016, The relational dynamics of enchantment and sacralization: Changing the terms of the religion versus secularity debate, Equinox, Sheffield.

Johnson, R.W., 2019, Fighting for the dream, Jonathan Ball Publishers, Johannesburg. Koch, A., 2014, Religionsökonomie: Eine Einführung, W. Kohlhammer, Stuttgart.

König, A., 1982, Hy kan weer en meer, N.G. Kerkboekhandel, Pretoria.

Kourie, C., 2015, 'Weaving colourful threads: A tapestry of spirituality and mysticism', HTS Teologiese Studies/Theological Studies 71(1), 1-9. https://doi.org/10.4102/ hts.v71i1.3023

Le Roux, J.H., 1994, 'God se brug na die mens: lets goddeliks of iets mensliks?', Skrif en Kerk 15(1), 27-51.

Lessing, G.E., 1979 [1777], 'Über den Beweis des Geistes und der Kraft', in H. Göpfert (Hrsg.) Werke, 8. Bd., Theologiekritische Schriften III, Philosophische Schriften, pp. 9-14, Hanser, München.

Lombaard, C., 2015, 'Deus ex Machina? Religious texts, spiritual capital and inequalities: In continuation of a current debate', Verbum et Ecclesia 36(1), 1-7. https://doi.org/10.4102/ve.v36i1.1378

Lombaard, C., 2016, 'Sensing a "second coming": An overview of new concepts in sociology, philosophy, law and theology on the re-emerging religious in private and public life', Verbum et Ecclesia 37(1), 1-6. https://doi.org/10.4102/ve. v37i1.1488

Lombaard, C., 2019, 'Weighing Schmitt's political theology anew: Implicit religion in politics', paper presented at the 'Pious radicals? Strong religion and politics in modern Europe' conference, Universität Siegen, Germany, 14-15th March.

Mcgrath, A.E., 1999, Christian spirituality: An introduction, Blackwell, Oxford.

Nolan, A., 1982, Biblical spirituality, The Order of Preachers, Springs.

Nürnberger, K., 1967, 'Glaube und Religion bei Karl Barth. Analyse und Kritik der verhältnisbestimmung zwischen dem christlichen Glauben und den anderen Religionen in $\S 17$ der "Kirchlichen Dogmatik" Karl Barths', DrTheol dissertation, Philipps-Universität Marburg, Marburg. 
Nürnberger, K., 1975, Sistematiese teologie, Teologiese Boekreeks, Genadendal.

Nürnberger, K., 1978a, 'Die Relevanz des Wortes im Entwicklungsprozess. Eine systematisch-theologische Besinnung zum Verhältnis zwischen Theologie und Entwicklungstheorie', DTh dissertation, University of South Africa.

Nürnberger, K., 1978b, Die Begegnung der Kirche mit Ideologien sozialen Wandels in Süd-Afrika, Allgemeine Hannoversche Missionskonferenz, Hannover.

Nürnberger, K. (ed.), 1978c, Affluence, poverty and the Word of God, Lutheran Publishing House, Durban.

Nürnberger, K., 1978d, 'The economics of Paul', in K. Nürnberger (ed.), Affluence, poverty and the Word of God, pp. 163-171, Lutheran Publishing House, Durban.

Nürnberger, K., 1981, 'The law-gospel debate as a possible basis for a theological ethic', Theologia Evangelica XIV, 25-47.

Nürnberger, K., 1983a, 'A consideration of the structure of economic society in South Africa (inaugural lecture', in W.S. Vorster (ed.), Church and industry, pp. 1-36, University of South Africa.

Nürnberger, K., 1984, Power, beliefs and equity: Economic potency structures in South Africa and their interaction with patterns of conviction in the light of a Christian ethic (Research report 04/PO17), Human Sciences Research Council, Pretoria.

Nürnberger, K., 1985, Maarten Luther se politieke etiek teen die agtergrond van sy teologiese benadering, Instituut vir Reformatoriese Studies, Potchefstroom.

Nürnberger, K., 1988, Power and beliefs in South Africa: Economic potency structures in South Africa and their interaction with patterns of conviction in the light of a Christian ethic, University of South Africa, Pretoria.

Nürnberger, K., 1990, The scourge of unemployment in South Africa, Encounter Publications, Pietermaritzburg.

Nürnberger, K., 1991a, 'Liberal democracies and its alternatives', in K. Nürnberger (ed.), A democratic vision for South Africa: Political realism and Christian responsibility, pp. 8-21, Lutheran World Federation, Geneva.

Nürnberger, K., 1991b, 'The seed that cracks the rock - The Biblical thrust towards democratic assumptions', in K. Nürnberger (ed.), A democratic vision for South Africa: Political realism and Christian responsibility, pp. 75-84, Lutheran World Federation, Geneva.

Nürnberger, K., 1991c, 'The reluctant insight - Protestantism and democracy', in K. Nürnberger (ed.). A democratic vision for South Africa: Political realism and Christian responsibility, pp. 175-187, Lutheran World Federation, Geneva.

Nürnberger, K., 1994a, An economic vision for South Africa: The task of the church in the post-apartheid economy, Encounter Publications, Pietermaritzburg.

Nürnberger, K., 1994b, 'The task of the church concerning the economy in a postapartheid South Africa', Missionalia 22(2), 118-146.

Nürnberger, K., 1994c, 'Discrepancies in the global economy as a challenge to the Christian message', in V. Mortensen (ed.), A just Africa: Ethics and the economy, pp. 47-70, Lutheran World Federation, Geneva.

Nürnberger, K., 1995, Making ends meet: Personal money management in a Christian perspective, Encounter Publications, Pietermaritzburg.

Nürnberger, K., 1998, Beyond Marx and market: Outcomes of a century of economic experimentation, Cluster Publications, Pietermaritzburg.

Nürnberger, K., 1999a, Prosperity, poverty and pollution: Managing the approaching crisis, Cluster Publications, Pietermaritzburg.

Nürnberger, K., 1999b, 'Theology in the light of universal evolution: Can the biblical faith be described adequately in terms of a radically inductive approach to reality?', in C.W. Du Toit (ed.), Reading the universe through science, religion and ethics: The evolving of science and religion debate, pp. 87-103, Research Institute for Theology and Religion, University of South Africa, Pretoria.

Nürnberger, K., 2002, Theology of the biblical witness: An evolutionary approach, LIT Verlag, Münster.

Nürnberger, K., 2004, Biblical theology in outline: The vitality of the word of God, Cluster Publications, Pietermaritzburg.

Nürnberger, K., 2006, Martin Luther's message for us today: A perspective from the South, Cluster Publications, Pietermaritzburg.

Nürnberger, K., 2007, The living dead and the living God: Christ and the ancestors in a changing Africa, Cluster Publications, Pietermaritzburg.

Nürnberger, K., 2009, Die Bybel: Verantwoordelik lees is krities lees, Lux Verbi, BM Wellington.

Nürnberger, K., 2010, Richard Dawkins' God delusion: A repentant refutation, Xlibris, London.
Nürnberger, K., 2012, 'Die einde van die wêreld: Die uitdaging van die moderne natuurwetenskappe aan die tradisionele eskatologie', HTS Teologiese Studies/ natuurwetenskappe aan die tradisionele eskatologie, HTS Teologiese
Theological Studies 68(1), 1-10. https://doi.org/10.4102/hts.v68i1.1254

Nürnberger, K., 2013, Informed by science-involved by Christ: How science can update, enrich and empower the Christian faith, Cluster Publications, Pietermaritzburg.

Nürnberger, K., 2016a, Faith in Christ today: Invitation to systematic theology. Volume I, Life in the presence of God, Xlibris, Dartford.

Nürnberger, K., 2016b, Faith in Christ today: Invitation to systematic theology. Volume II, Involved in God's project, Xlibris, Dartford.

Nürnberger, K., 2019, Speaking in the name of God: A manual for preachers, Xlibris, Dartford.

Nynäs, P., Lassander, M. \& Utriainen, T. (eds.), 2012, Post-secular society, Transaction Publishers, New Brunswick.

Otto, E. (hrsg.), 2005, Weber, Max: Die Wirtschaftsethik der Weltreligionen: Das Antike Judentum: Schriften und Reden 1911-1920 (Max Weber-Gesamtausgabe, Band I/21,1 \& 2), Mohr Siebeck, Tübingen.

Pretorius, S., 2008, 'Understanding spiritual experience in Christian spirituality', in P. De Villiers, C. Kourie \& C. Lombaard (eds.), The spirit that empowers: Perspectives on spirituality, Acta Theologica Supplementum 11, pp. 147-165, University of the Free State Press, Bloemfontein.

Ricoeur, P., 1970, Freud and philosophy: An essay on interpretation, Yale University Press, New Haven, CT.

Rosa, H. \& Henning, C. (eds.), 2017, The good life beyond growth: New perspectives, Routledge, London.

Rosner, D., 1978, 'The balance of economic security and income according to the Mosaic Law (the Torah)', in K. Nürnberger (ed.), Affluence, poverty and the Word of God, pp. 135-140, Lutheran Publishing House, Durban.

Sands, J., 2018, Reasoning from faith, Indiana University Press, Bloomington, IN.

Schmitt, C., 1934 [1922], Politische Theologie: Vier Kapitel zur Lehre von der Souveränität (2. Auflage), Verlag Von Duncker \& Humblot, München.

Schmitt, C., 2008 [1970], Politische Theologie II. Die Legende von der Erledigung jeder politischen Theologie (5. Auflage), Duncker \& Humblot, Berlin.

Schreiber, D., 2012, 'On the epistemology of postmodern spirituality', Verbum et Ecclesia 33(1), 1-8. https://doi.org/10.4102/ve.v33i1.398

Seekings, J. \& Natrass, N., 2016, Policy, politics and poverty in South Africa, Jacana, Cape Town.

Sen, A., 2005, 'Development as capability expansion', in S. Fukuda-Parr \& S. Kumar (eds.), Readings in human development, pp. 3-16, Oxford University Press, New Delhi.

Scheffler, E.H., 2011, 'Pleading poverty (or identifying with the poor for selfish reasons): On the ideology of Psalm 109', Old Testament Essays 24(1), 192-207.

Schlemmer, L., 1978, 'The two significant income gaps in South Africa', in K. Nürnberger (ed.), Affluence, poverty and the Word of God, pp. 49-56, Lutheran Publishing House, Durban.

Spivak, G.C., 1988, 'Can the subaltern speak?', in C. Nelson \& L. Grossberg (eds.), Marxism and the interpretation of culture, pp. 271-313, University of Illinois Marxism and the
Press, Urbana, IL.

Stackhouse, M.L., 1987, Public theology and political economy: Christian Stewardship in modern society, Eerdmans, Grand Rapids, MI.

Tawney, R.H., 1969 [1926], Religion and the rise of capitalism, Penguin, Harmondsworth.

Taylor, C., 2007, A secular age, Harvard University Press, Cambridge, MA.

Taylor, R.K., 1973, Economics and the Gospel. A primer on shalom as economic justice, United Church Press, Philadelphia, PA.

Van den Berg, A., 1998, God and the economy, Eburon Publishers, Delft.

Van Onselen, C., 1996, The seed is mine: The life of Kas Maine, a South African sharecropper, 1894-1985, James Currey, Oxford.

Van Wyk, W.C., 2011, 'Aktuele Bybelinterpretasie in Suid-Afrika - 'n kort oorsig en toepassing', HTS Teologiese Studies/Theological Studies 67(3), 1-7.

Von Rad, G., 1969, Theologie des Alten Testaments (Band 1; 6. Auflage), Chr. Kaiser Verlag, München.

Weber, M., 1926, The Protestant ethic, Allen \& Unwin, London.

West, G., 1991/1995, Biblical hermeneutics of liberation. Modes of reading the Bible in the South African context, 2nd edn., Cluster Publications, Pietermaritzburg.

Wittenberg, G., 1978, 'The message of the Old Testament prophets during the eighth century B.C. concerning affluence and poverty', in K. Nürnberger (ed.), Affluence, poverty and the Word of God, pp. 141-152, Lutheran Publishing House, Durban. 